\title{
Platelet dysfunction: a new dimension in inflammatory bowel disease
}

Until recently, interest in the role of platelets in inflammatory bowel disease (IBD) was confined to an awareness of thrombocytosis as a marker of disease activity, ${ }^{1}$ and as a possible predisposing factor to systemic thromboembolism. Two recent conceptual advances suggest that platelets may contribute to the pathogenesis of IBD at the mucosal level. Firstly, it is now recognised that platelets themselves participate in the inflammatory response by acting as a potent source of inflammatory mediators and modulating the activity of other inflammatory cells. ${ }^{2}$ Secondly, multifocal microinfarction in the mesenteric vasculature has been proposed as an early event in the pathogenesis of Crohn's disease ${ }^{3}$; this hypothesis has drawn attention again to earlier speculation about a vascular origin for ulcerative colitis. ${ }^{45} \mathrm{We}$ discuss here the evidence for a pathogenic role for platelets in IBD, and possible therapeutic implications of this.

\section{Platelets as inflammatory cells}

Platelets are capable of directly eliciting an inflammatory response. Injection of extracts of platelets into the skin of healthy volunteers produces a strong inflammatory reaction - rubor, dolor, calor, and turgor - which persists for several hours. ${ }^{6}$ Extracts of neutrophils and basophils fail to produce this reaction and eosinophils give only an early histamine-like response. Over the last two decades, the proinflammatory properties of platelets have gradually been elucidated ${ }^{2}$; those which may be important in IBD are described.

RELEASE OF INFLAMMATORY MEDIATORS

Activated platelets release a range of inflammatory mediators including platelet activating factor (PAF), thromboxane (TX), 12-hydroxyeicosatetraenoic acid (12-HETE), platelet factor 4 (PF4), serotonin, platelet derived growth factor (PDGF), and transforming growth factor beta (TGF $\beta$ ). Platelets are also capable of producing oxygen free radicals, via IgE receptor mediated activation. ${ }^{7}$ As well as contributing to chemoattraction and activation of other inflammatory cells (see below), some of these platelet derived mediators may increase vascular permeability and modulate vascular tone. ${ }^{89}$

\section{RECRUITMENT AND CHEMOTAXIS OF OTHER}

INFLAMMATORY CELLS

Activated platelets are capable of promoting recruitment of neutrophils by surface expression of P-selectin, the specific adhesion molecule for neutrophil attachment. ${ }^{10}$ Release of PF4, 12-HETE, PDGF, and TGF $\beta$ causes chemoattractant of neutrophils, monocytes, and eosinophils. ${ }^{11-14}$ PF4, once discharged from activated platelets, is rapidly taken up by endothelial cells ${ }^{11}$ and may be important in directing neutrophils to the endothelium prior to diapedesis. Serotonin promotes neutrophil adhesion to endothelium ${ }^{15}$ and activated platelets may themselves directly induce endothelial cell secretion of interleukin-8 which enhances neutrophil diapedesis. ${ }^{16}$

\section{MODULATION OF ACTIVITY OF OTHER INFLAMMATORY}

CELLS

PAF production by neutrophils is greatly enhanced in the presence of platelets. ${ }^{17}$ Platelets and neutrophils cooperatively synthesise a range of chemoattractant lipoxygenase products which cannot be made by either cell type alone. ${ }^{18}$ Platelet derived 12-HETE enhances monocyte procoagulant activity. ${ }^{19}$ PDGF and TGF $\beta$ promote mitogenesis in fibroblasts ${ }^{2014}$ and may thereby stimulate local fibrosis and angiogenesis.

\section{Platelets in vascular disease}

In view of the compelling evidence that abnormalities within mesenteric blood vessels contribute to the pathogenesis of IBD, ${ }^{3-5}$ it is of interest that abnormal platelet behaviour is seen in other disorders in which vascular pathology is a feature.

In ischaemic heart disease, for example, increased platelet aggregation in vitro ${ }^{2122}$ and increased mean platelet volume $^{23}$ predict coronary events and mortality. Moreover, antiplatelet therapy is of proved benefit in reducing morbidity and mortality. ${ }^{24} 25$ Platelets have also been implicated in the pathogenesis of vascular disease associated with diabetes mellitus. Increased platelet aggregation in vitro, serum $\beta$ thromboglobulin ${ }^{26}$ and platelet activation (as indicated by expression of the surface markers P-selectin and GP53) ${ }^{27}$ have all been reported.

\section{Evidence for abnormal platelet function in IBD}

That platelets can behave as inflammatory cells and that mesenteric microinfarction may have a role in the pathogenesis of Crohn's disease provide the basis for the hypothesis that platelets may participate in the inflammatory process in the intestinal mucosa of patients with IBD.

Laboratory assessment of platelet behaviour can be compromised by the susceptibility of platelets to in vitro activation. Measurement of platelet size and survival are also subject to artefact and require careful standardisation and interpretation. Recent work using more reliable methods has provided increasing evidence for abnormalities of platelet function and morphology in IBD.

PLATELET AGGREGATION IN VITRO

Traditional Born aggregometry ${ }^{28}$ allows in vitro assessment of platelet response to aggregating agents. Spontaneous platelet aggregation ${ }^{29-33}$ has been documented in patients with IBD including those in remission, 
and increased sensitivity to adenosine diphosphate, arachidonic acid, ristocetin, collagen, and thrombin ${ }^{32-34}$ has also been described.

\section{PLATELET AGGREGATE FORMATION IN VIVO}

Circulating platelet aggregates in venous blood have been identified in active Crohn's disease and ulcerative colitis. ${ }^{34}$ Histological examination of rectal biopsies reveals intra-capillary platelet aggregates in patients with ulcerative colitis, Crohn's disease and also in those with self-limiting infective colitis ${ }^{35}$ but not in control (normal) biopsies.

\section{ACTIVATION DEPENDENT PLATELET SURFACE ANTIGENS P-SELECTIN AND GP53}

The functional status of circulating platelets in vivo can be assessed using single cell flow cytometry. The glycoproteins P-selectin (the neutrophil adhesion molecule) and GP53 (whose function is unknown) are extruded to the platelet surface membrane during activation and can be detected using specific fluorescent antibodies. Increased expression of these markers is seen in peripheral venous blood in Crohn's disease and in ulcerative colitis, independently of disease activity. ${ }^{36} 37$ P-selectin expression is greater in finger-tip capillary blood than in venous blood in normal individuals; this difference is exaggerated in patients with Crohn's disease, implying that their platelets are more susceptible to activation in the microcirculation. ${ }^{38}$

\section{SERUM PROTEINS DERIVED FROM PLATELET GRANULES}

$\beta$ Thromboglobulin ( $\beta T G$ ) and PF4 are discharged from alpha granules at activation and can be measured in serum using radioimmunoassay or enzyme linked immunosorbent assay. Standardised venesection technique and handling of samples is important to avoid falsely raised levels of these proteins due to in vitro platelet activation. BTG and PF4 are discharged from platelets at similar rates but in vivo PF4 is rapidly taken up by endothelium; artefactually high levels may therefore be identified by examining the $\beta T G / P F 4$ ratio for each specimen. ${ }^{39}$ Increased serum concentrations of these two markers individually have been reported in ulcerative colitis and Crohn's disease both in remission and relapse ${ }^{33} 40$; the results imply either increased platelet activation in vivo or a reduced threshold for activation in vitro.

\section{PLATELET SIZE}

Automated counters routinely produce a value for mean platelet volume. However, time dependent shape, and hence volume, changes occur after venesection and this varies with the anticoagulant used. ${ }^{41}$ The mean platelet volume, assessed by validated methods, and the platelet count are normally inversely related ${ }^{42}$; studies on the mean platelet volume in IBD using various methods have shown smaller mean platelet volume compared with controls, ${ }^{43} 44$ consistent with the increased platelet count seen in IBD subjects.

\section{PLATELET SURVIVAL}

Standardisation of the measurement of platelet survival in healthy subjects and in disease states using radiolabelled platelets is controversial. The first report of platelet survival in IBD showed a decreased half-time ${ }^{45}$ and a more recent study showed a similar trend. ${ }^{33}$ Since the platelet count is raised in active IBD, these results suggest a greatly increased rate of platelet production.

\section{Why are platelet function and morphology abnormal in IBD?}

There are several possible mechanisms for increased platelet activation in IBD. Endothelial cell damage in the mesenteric vasculature exposes basement membrane collagen, to which platelets are exquisitely sensitive, and this could trigger platelet activation. The increase in serum von Willebrand factor (a marker of endothelial cell damage) found in IBD, in Crohn's disease independently of disease activity, is consistent with this possibility. ${ }^{46}$ Release of $\mathrm{PAF}^{47}$ and thromboxane $\mathrm{A}_{2}{ }^{33}$ from platelets or activated neutrophils into the mesenteric circulation at the site of intestinal disease could perpetuate or amplify platelet activation; monocytes and neutrophils activated by endotoxin ${ }^{48}$ or other absorbed bacterial products could also stimulate platelets. ${ }^{49}$ Virus induced changes in the endothelium could promote platelet adherence and activation in vitro before any detectable endothelial cell disruption ${ }^{50}$; this observation is particularly interesting in the light of the recent report of persisting measles infection in foci of granulomatous vasculitis in Crohn's disease tissue. ${ }^{51}$

The evidence relating to platelet count, size, and survival is as yet more difficult to explain. Circulating platelet count is the net result of the balance between rates of production and destruction. Factors responsible for stimulating thrombopoiesis include interleukins 3 and 6 , and thrombopoietin, ${ }^{52}$ and circulating interleukin 6 at least is raised in active Crohn's disease. ${ }^{53}$ The published data suggesting that, despite being activated, platelets in IBD are small 334344 presents a paradox: in ischaemic heart and diabetic vascular disease, for example, platelets are activated but large, ${ }^{23} 27$ consistent with previous evidence that the reactivity of subpopulations of platelets correlates positively with their volume. ${ }^{54}$ Platelet size is probably determined at the time of thrombopoiesis; no significant change takes place during the time the individual platelet spends in the circulation. ${ }^{55}$ Determination of platelet size is complex and is influenced by megakaryocyte volume and ploidy. ${ }^{56}$ Platelet destruction rate, platelet thromboxane production, and the bleeding time contribute to the complex feedback mechanism which determines the properties of megakaryocytes ${ }^{56}$; different profiles of these variables in IBD and ischaemic heart disease may account for the contrasting mean platelet volume in these diseases. Alternatively, reduced mean platelet volume in the peripheral circulation in IBD could be explained by consumption or sequestration of large activated platelets in the intestinal vasculature. Although such a phenomenon would contribute to reduced platelet survival, attempts to image sequestration in the mesenteric vasculature in IBD using radiolabelled platelets have proved inconclusive so far. ${ }^{33}$

\section{Pathogenetic consequences of abnormal platelet function in IBD}

Activated hyperaggregable platelets may contribute to the pathogenesis of the mucosal lesion in IBD by local release of inflammatory mediators, and chemoattraction and activation of other inflammatory cells, as described earlier. Platelet phospholipid membrane is the primary site for assembly of the coagulation factors essential for the generation of thrombin and consequently fibrin ${ }^{57}$; it is therefore possible that a platelet abnormality underlies the procoagulant state observed in IBD. Expression of P-selectin on the platelet surface membrane promotes neutrophil accumulation and fibrin deposition at the site of vascular injury. ${ }^{58}$ Circulating platelet aggregates could precipitate ischaemic damage by occluding intestinal 
microvasculature; platelet derived thromboxane $A_{2}$ could exacerbate ischaemia by inducing local vascoconstriction. PDGF and TGF $\beta$ may be important in stricture formation, particularly in Crohn's disease, as well as in the physiological repair mechanisms which follow tissue damage. Platelet aggregate derived PDGF in the digital microcirculation has been implicated in the aetiology of finger clubbing in patients with right to left haemodynamic shunts ${ }^{59}$ and could contribute to clubbing in Crohn's disease. ${ }^{60}$

\section{Therapeutic implications of platelet dysfunction in IBD}

If platelet dysfunction does play a major role in the pathogenesis of IBD, agents which reduce platelet activity should prove useful in its treatment. Indeed, selective antithromboxane agents (whose effects in vivo include inhibition of platelet aggregation) suppress inflammation associated with the trinitrobenzenesulphonic acid model of colitis, endotoxin induced intestinal damage, and NSAID induced small bowel ulceration in rats. ${ }^{61-63}$

Sulphasalazine inhibits platelet aggregation, at least in vitro $^{64}$; however, the high concentration required for this action $\left(\mathrm{IC}_{50} 2 \mathrm{mM}\right)$ and its many other pharmacological effects, ${ }^{65}$ preclude the conclusion that sulphasalazine works in vivo primarily by this mechanism.

Low dose aspirin also inhibits platelet aggregation by reducing platelet $\mathrm{TX}$ synthesis and may be worth assessment in IBD; higher doses, however, as with NSAIDs, may have a detrimental effect by inhibiting prostaglandin synthesis, enhancing leucotriene synthesis, or through other actions. ${ }^{6667}$ Specific dual TX synthesis inhibitors and receptor antagonists are now available for use in man. Ridogrel (Janssen), in a preliminary study, seemed to benefit patients with ulcerative colitis ${ }^{68}$ and, like Picotamide (Samil Gruppo), an agent in use in Europe for treatment of arterial vascular disease for some years, is now undergoing clinical trial in IBD.

\section{Conclusion}

There is now good evidence that platelet function is abnormal in Crohn's disease and ulcerative colitis, independently of disease activity. Confirmation that increased platelet activity contributes to the pathogenesis of the mucosal lesion in IBD awaits the results of therapeutic trials with specific antiplatelet agents. A successful outcome to such clinical studies would add a new dimension to the treatment of patients with IBD.

GI Science Research Unit,

CAROLE E COLLINS

The London Hospital Medical College,

26 Ashfield Street,

Whitechapel, London E1 $2 A \mathcal{F}$

1 Harries AD, Fitzsimmons E, Fifield R, Dew MJ, Rhodes J. Platelet count; a simple measure of activity in Crohn's disease. BMF 1983; 286: a simple

2 Weksler BB. Platelets. In: Gallin JI, Goldstein IM, Snyderman R, eds. Inflammation: basic principles and clinical correlates. 2nd ed. New York: Raven Press, 1992: 727-46.

3 Wakefield AJ, Sawyerr AM, Dhillon AP, Pittilo RM, Rowles PM, Lewis AAM, et al. Pathogenesis of Crohn's disease: multifocal gastrointestinal infarction. Lancet 1989; ii: 1057-62.

4 Donnellan WL. Early histological changes in ulcerative colitis; a light and electron microscopic study. Gastroenterology 1966; 50: 519-40.

5 Fairburn RA. On the aetiology of ulcerative colitis; a vascular hypothesis. Lancet 1973; ii: 697-9.

6 Day RP, Behmann S, Dolovich J, Hargreaves FE. Inflammatory effects of leucocytes and platelets. F Allerg Clin Immun 1975; 55: 87.

7 Ameisen JC, Capron A, Joseph M, Maclouf J, Vorng H, Pancre V, et al. Aspirin-sensitive asthma: abnormal platelet response to drugs inducing asthmatic attacks. Int Arch Allergy Appl Immunol 1985; 78: 438-48.
8 Braquet P, Touqui L, Shen TY, Vargaftig BB. Perspectives in plateletactivating factor research. Pharmacol Rev 1987; 39: 97-145.

9 Berk BC, Alexander RW, Brock TA, Gimbrone MA, Webb RC. Vasoconstriction; a new activity for platelet-derived growth factor. Science 1986; 232: 87-90.

10 Larsen E, Celi A, Gilbert GE, Furie BC, Erban JK, Bonfanti R, et al. PADGEM protein: a receptor that mediates the interaction of activated PADGEM protein: a receptor that mediates the interaction of action

11 Deuel TF, Senior RM, Chang D, Griffin GL, Heinrikson RL, Kaiser ET. Platelet factor 4 is chemotactic for neutrophils and monocytes. Proc Natl Acad Sci USA 1981; 78: 4584-7.

12 Goetzl EJ, Woods JM, Gorman RR. Stimulation of human eosinophil and neutrophil polymorphonuclear leukocyte chemotaxis and random migration by 12 -L-hydroxy-5,8,10,14-eicosatetraenoic acid. $\mathcal{f}$ Clin Invest 1977 ; 59: 179-83.

13 Deuel TF, Senior RM, Huang JS, Griffin GL. Chemotaxis of monocytes and neutrophils to platelet-derived growth factor. $\mathcal{F}$ Clin Invest 1982; 69: 1046-9.

14 Wahl SM, Hunt DA, Wakefield LM, McCartney-Francis N, Wahl LM, Roberts AB, et al. Transforming growth factor type beta induces monocyte chemotaxis and growth factor production. Proc Natl Acad Sci USA 1987; 63: 943-5.

15 Boogaerts MA, Yamada O, Jacob HS, Moldow CF. Enhancement of granulocyte-endothelial cell adherence and granulocyte-induced cytotoxicity by platelet release products. Proc Natl Acad Sci USA 1982; 79; 7019-23.

16 Kaplanski G, Porat R, Aiura K, Erban JK, Gelfand JA, Dinarello CA. Activated platelets induce endothelial secretion of interleukin- 8 in vitro via an interleukin-1 mediated event. Blood 1993; 81: 2492-5.

17 Coeffier E, Delautier D, LeCouedic J, Chignard M, Denizot Y, Beneviste J. Cooperation between platelets and neutrophils for PAF- acether (platele activating factor) formation. F Leukoc Biol 1990; 47: 234-43.

18 Maclouf J, Fitzpatrick FA, Murphy RC. Transcellular biosynthesis of eicosanoids. Pharmacol Res 1989; 21: 1-18.

19 Lorenzet R, Niemetz J, Marcus AJ, Broekman MJ. Enhancement of mononuclear procoagulant activity by platelet 12 -hydroxyeicosatetraenoic acid. 7 Clin Invest 1986; 78: 418-23.

20 Ross R, Raines EW, Bowen-Pope DF. The biology of platelet-derived growth factor. Cell 1986; 46: 155-69.

21 Trip MD, Cats VM, van Capelle FJL, Vreeken J. Platelet hyperreactivity and prognosis in survivors of myocardial infarction. $N$ Eng $\mathscr{F}$ Med 1990; 322: $1549-54$

22 Elwood PC, Renaud S, Sharp DS, Beswick AD, O'Brien JR, Yarnell JW. Ischemic heart disease and platelet aggregation; the Caerphilly collaborative heart disease study. Circulation 1991; 83: 38-44.

23 Martin JF, Bath PMW, Burr ML. Influence of platelet size on outcome after myocardial infarction. Lancet 1991; 338: 1409-11.

24 ISIS-2 (second international study of infarct survival) collaborative group. Randomised trial of intravenous streptokinase, oral aspirin, both or group. Randomised trial of intravenous streptokinase, oral aspirin, both or ISIS-2. Lancet 1988; ii: 349-60.

25 Antiplatelet trialists' collaboration. Secondary prevention of vascular disease by prolonged antiplatelet treatment. $B M F$ 1988; 296: 320-31.

26 Janka HU, Standl E, Schramm W, Mehnert H. Platelet enzyme activities in diabetes in relation to endothelial damage. Diabetes 1983; 32 (suppl 2): 47-51.

27 Tschoepe D, Roesen P, Esser J, Schwippert B, Nieuwenhuis HK, Kehrel B, et al. Large platelets circulate in an activated in diabetes mellitus. Semin Thromb Hemost $1991 ; 17$ (4): 433-8.

28 Born GVR. Aggregation of blood platelets by adenosine diphosphate and its reversal. Nature 1962; 194: 927-9.

29 Knot E, Ten Cate JW, Leeksma OCH, Tytgat GN, Vreeken J. No evidence for a prethrombotic state in stable chronic inflammatory bowel disease. for a prethrombotic state in stab

30 Mori K, Watanabe H, Hiwatashi N, Sugai K, Goto Y. Studies on blood coagulation in ulcerative colitis and Crohn's disease. Tohoku $\mathcal{F}$ Exp Med 1980; 132: 93-101.

31 Lake AM, Stauffer JQ, Stuart MJ. Hemostatic alterations in inflammatory bowel disease; response to therapy. Dig Dis 1978; 23: 897-902.

32 van Wersch JWJ, Houben P, Rijken J. Platelet count, platelet function, coagulation activity and fibrinolysis in the acute phase of inflammatory bowel disease. 7 Clin Chem Clin Biochem 1990; 28: 513-7.

33 Webberly MJ, Hart MT, Melikian V. Thromboembolism in inflammatory bowel disease; role of platelets. Gut 1993; 34: 247-51.

34 Collins CE, Cahill MR, Newland AC, Rampton DS. Platelets circulate in an activated state in inflammatory bowel disease. Gastroenterology 1994; 106: 840-5.

35 Dhillon AP, Anthony A, Sim R, Wakefield AJ, Sankey EA, Hudson M, et al. Mucosal capillary thrombi in rectal biopsies. Histopathology 1992; 21: 127-33.

36 Tschoepe D, Niederau C, Schwippert B, Schumacher B, Niewenhuis HK, Strohmeyer G. Platelets of patients with Crohn's disease circulate in an activated state. Gastroenterology 1993; 104: A793.

37 Schaufelberger HD, Uhr MR, Smith AC, Logan RPH, Gordon-Smith EC, Misiewicz JJ. Platelet activation in inflammatory bowel disease. Gut 1993; 34: 550.

38 Tschoepe D, Schwippert B, Schumacher B, Strauss K, Jackson A, Niederau C. Increased P-selectin (CD62) expression on platelets from capillary whole blood of patients with Crohn's disease. Gastroenterology 1993; 104: A793.

39 Kaplan KL, Owen J. Plasma levels of beta-thromboglobulin and platelet factor 4 as indices of platelet activation in vivo. Blood 1981; 57: platelet facto $199-202$.

40 Simi M, Leardi S, Tebano MT, Castelli M, Costantini FM, Speranza V. Raised plasma concentrations of platelet factor 4 (PF4) in Crohn's Raised plasma concentration

41 Trowbridge EA, Reardon DM, Hutchinson D, Pickering C. The routine measurement of platelet volume: a comparison of light-scattering and aperture-impedance technologies. Clin Phys Physiol Meas 1985; 6: 221-38.

42 Levin J, Bessman JD. The inverse relationship between platelet volume and platelet number. F Lab Clin Med 1983; 101: 295-307.

43 Shah A, Morgan G, Rose JDR, Fifield R, Rhodes J. Platelet number and size in relation to serum orosomucoid concentration in Crohn's disease. Med Lab Sci 1989; 46: 79-80. 
44 Collins CE, Cahill MR, Rampton DS. Paradoxical association between increased platelet activation and reduced platelet volume in Crohn's disease. Gut 1993; 34: S63.

45 Talstad I, Rootwelt K, Gjone E. Thrombocytosis in ulcerative colitis and Crohn's disease. Scand f Gastroenterol 1973; 8: 135-8.

46 Stevens TRI, James JP, Simmonds NJ, McCarthy DA, Laurenson IF, Maddison PG, et al. Circulating von Willebrand factor in inflammatory Maddison PG, et al. Circulating von

47 Eliakim R, Karmeli F, Razin E, Rachmilewitz D. Role of platelet-activating factor in ulcerative colitis. Gastroenterology 1988; 95: 1167-72.

48 Wellman W, Fink PC, Benner F, Schmidt FW. Endotoxaemia in active Crohn's disease. Treatment with whole gut irrigation and 5-aminosalicylic acid. Gut 1986; 27: 814-20.

49 Schwartz BS, Monroe MC. Human platelet aggregation is initiated by peripheral blood mononuclear cells exposed to bacterial lipopolysaccharide in vitro. $\mathcal{F}$ Clin Invest 1986; 78: 1136-41.

50 Visser MR, Tracy PB, Vercellotti GM, Goodman JL, White JG, Jacob HS. Enhanced thrombin generation and platelet binding on herpes simplex virus-infected endothelium. Proc Natl Acad Sci USA 1988; 85: 8227-30.

51 Wakefield AJ, Pittilo RM, Sim R, Cosby SL, Stephenson JR, Dhillon AP, et al. Evidence of persistent measles infection in Crohn's disease. $\mathcal{F}$ Med Virol 1993; 39: $345-53$.

52 Bennett JS, Shattil SJ. Platelet function. In: Williams JW, Beutler E, Erslev AJ, Lichtman MA, eds. Hematology. 4th ed. New York: McGraw-Hill, 1991: 1233-50.

53 Mahida YR, Kurlac L, Gallagher A, Hawkey CJ. High circulating concentrations of interleukin- 6 in active Crohn's disease but not ulcerative colitis. Gut 1991; 32: 1531-4

54 Thompson CB, Jakubowski JA, Quinn PG, Deykin D, Valeri CR. Platelet size and age determine platelet function independently. Blood 1984; 63: 1372-5.

55 Thompson CB, Love DG, Quinn PG, Valeri CR. Platelet size does not correlate with platelet age. Blood 1983; 62: 487-64.

56 Martin JF, Trowbridge EA, Salmon G, Plumb J. The biological significance of platelet volume: its relationship to bleeding time, platelet thromboxane production $\mathrm{B}_{2}$ production and megakaryocyte nuclear DNA concentration. Thromb Res 1983; 32: 443-60.

57 Paulus J-M, Aster RH. Production, distribution, life-span, and fate of platelets. In: Williams JW, Beutler E, Erslev AJ, Lichtman MA, eds. Hematology. 4th ed. New York: McGraw-Hill, 1991: 1251-60.

58 Palabrica T, Lobb R, Furie BC, Aronitz M, Benjamin C, Hsu YM, et al. Leukocyte accumulation promoting fibrin deposition is mediated et al. Leukocyte accumulation promoting fibrin deposition is mediated
in vivo by P-selectin on adherent platelets. Nature 1992; 359 (6398): in vivo by

59 Dickinson CJ, Martin JF. Megakaryocytes and platelet clumps as the cause of finger clubbing. Lancet 1987; i: 1434-5.

60 Collins CE, Cahill MR, Rampton DS. Clubbing and Crohn's disease [Letter]. BMF 1993; 307: 508

61 Vilaseca J, Salas A, Guarner F, Rodriguez R, Malagelada JR. Participation of thromboxane and other eicosanoid synthesis in the course of experimental inflammatory colitis. Gastroenterology 1990; 98: 269-77.

62 Boughton-Smith NK, Hutcheson I, Whittle BJ. Relationship between PAF-acether and thromboxane $A_{2}$ biosynthesis in endotoxin-induced intestinal damage in the rat. Prostaglandins 1989; 38: 319-33.

63 Baneriee AK, Peters TRJ. Experimental NSAID induced enteropathy in the rat; similarities to IBD and the effect of TX synthetase inhibitors. Gut 1990; 31: 1358-63.

64 Boughton-Smith NK, Hawkey CJ, Rosam AC, Whittle BRJ. Sulphasalazine inhibits platelet aggregation, and thromboxane formation in human platelets and colon. Br F Pharmacol 1986; supp 88: $391 \mathrm{P}$

65 Greenfield SM, Punchard NA, Teare JP, Thompson RPH. Review article: the mode of action of aminosalicylates in inflammatory bowel disease. Aliment Pharmacol Ther 1993; 7: 369-83.

66 Rampton DS. Non-steroidal anti-inflammatory drugs and the lower gastrointestinal tract. Scand f Gastroenterol 1987; 22: 1-4.

67 Kaufman HJ, Taubin HL Non-steroidal anti-inflammatory drugs activate quiescent inflammatory disease. Ann Intern Med 1987; 107: 513-6.

68 Casellas F, Papo M, Guarner F, Antolin M, Segura RM, Armengol JR, et al. A selective thromboxane synthetase inhibitor improves chronic ulcerative colitis. Gastroenterology 1993; 104: A677. 